\title{
Diagnosis of Lead Pollution of Surface Waters of a River: Case of the Djiri River in the Republic of Congo
}

\author{
Roch Corneille Ngoubou', Jean Bienvenu Dinga ${ }^{2}$, Dominique Nganga1 \\ ${ }^{1}$ Faculty of Sciences and Techniques, Doctoral Training in Environmental Geosciences (University Marien NGOUABI), \\ Brazzaville, Congo \\ ${ }^{2}$ Laboratory of Physico-Chemical Analysis of the Institute for Research in Exact and Natural Sciences, Scientific Research, \\ Brazzaville, Congo \\ Email: Corneillerochdesuz@gmail.com, bvs_dinga@yahoo.fr
}

How to cite this paper: Ngoubou, R.C., Dinga, J.B. and Nganga, D. (2021) Diagnosis of Lead Pollution of Surface Waters of a River: Case of the Djiri River in the Republic of Congo. Journal of Water Resource and Protection, 13, 173-189.

https://doi.org/10.4236/jwarp.2021.133010

Received: December 18, 2020

Accepted: March 6, 2021

Published: March 9, 2021

Copyright $\odot 2021$ by author(s) and Scientific Research Publishing Inc. This work is licensed under the Creative Commons Attribution International License (CC BY 4.0).

http://creativecommons.org/licenses/by/4.0/

\section{Open Access}

\begin{abstract}
This research work focuses on the physico-chemical analysis of surface water from the Djiri River with the aim of preventing the population against possible water pollution. The analysis of samples taken from the Djiri river revealed the presence of lead in these waters at levels exceeding the WHO guideline values: an average annual pollution $(0.93 \mathrm{mg} / \mathrm{l})$ which is visibly higher than the value. WHO guide $(0.01 \mathrm{mg} / \mathrm{l})$ in situ data from the Djiri River revealed a significant drop in flow between the 2016 period characterized by a divergence index of 0.82344 , thus highlighting a hydrological situation for which national hydrological stakeholders will absolutely have to implement measures, remedial measures or mechanisms to protect this river against possible disappearance by elimination of lead in the water.
\end{abstract}

\section{Keywords}

Metallic Pollution, Water Quality Standards, Indicators and Degree of Pollution

\section{Introduction}

The Djiri river is located in the 8th arrondissement of Brazzaville, with a flow of $25 \mathrm{~m}^{3} / \mathrm{s}$, it flows into the Congo river. The demographic growth of the city of Brazzaville has pushed many populations to occupy plots of land over the past ten years and to live in the Djiri district, so all around the Djiri river are dwellings where Socioeconomic activities are carried out.

The riparian populations use the waters of the Djiri for various uses like 
Swimming; Laundry; Washing up; Food washing.

An electric steelworks is erected $1 \mathrm{~km}$ from the Djiri bridge (1st exit). It is likely to release toxic particles into the waters of the Djiri River that can cause damage to the environment in general and to human health in particular.

This work is part of the protection of the water ecosystem and the health risk coverage of neighboring populations.

Indeed, the problem of water pollution is closely linked to that of water quality and requires special attention in the Congo as in most developing countries; the faster a diagnosis of poor quality of water for use is made, the quicker the means can be implemented to provide solutions to cover health and environmental risks.

During this study, we estimated the physico-chemical and metallic quality of Djiri's surface water from two sampling points: Djiri Station (Upstream Point) and Old Djiri Manianga Bridge (Downstream Point).

Twelve months of sampling and physicochemical analyses have made it possible to demonstrate overall the pollutant nature of lead, the relative values of which for the monthly in situ measurement excess are strictly positive and consequently of the values of the pollution index strictly higher than the unit characterizing an exceeding of the WHO guide values for this metal [1]. Lead is a point source of pollution.

\section{Materials and Methodologies}

\subsection{Materials}

The reagents, hardware and software requirements necessary for the implementation of the sampling process, physico-chemical analyzes and analysis of the data resulting from the physico-chemical characterization of the water are summarized in Table 1.

Table 1. Equipment, Product and Software for the acquisition of data from physico-chemical analyzes of water.

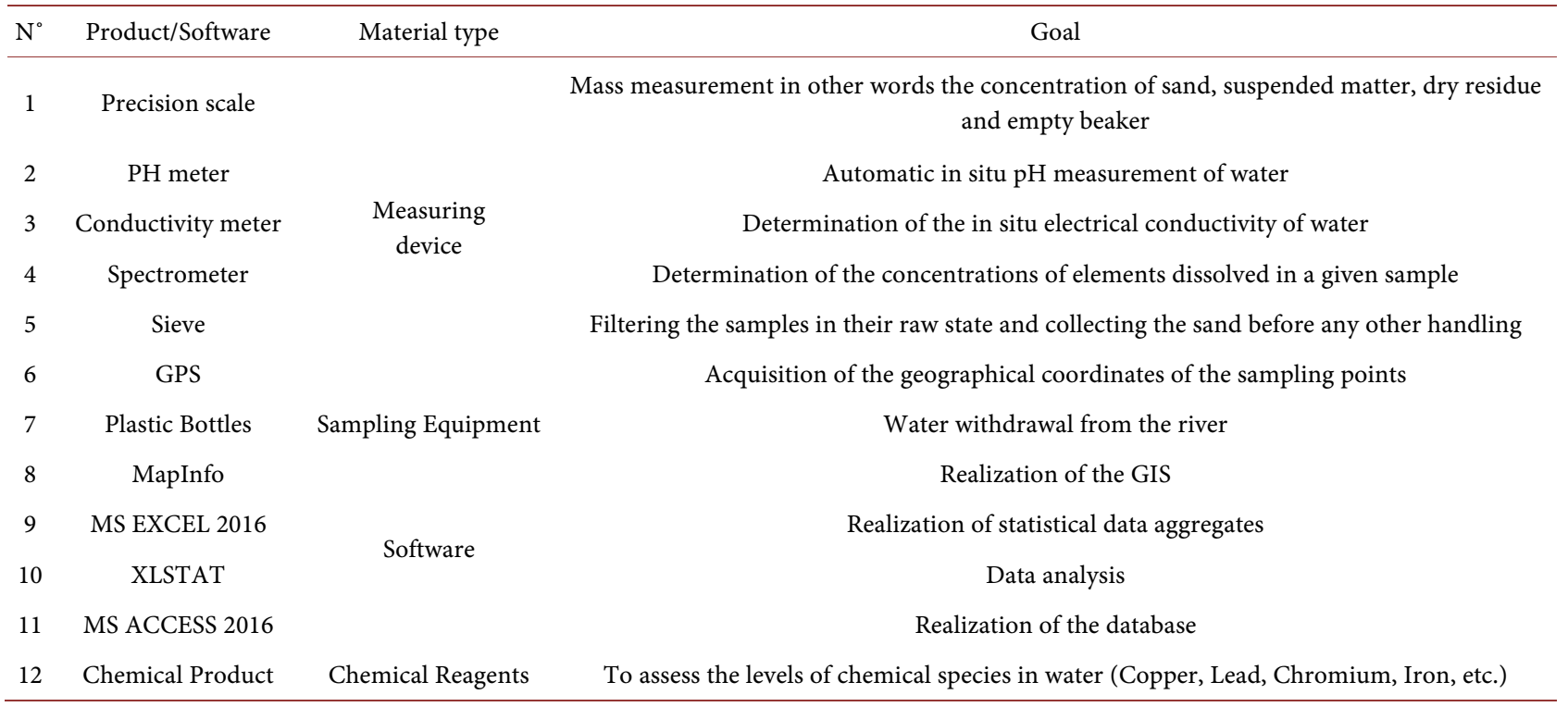

Source: Field data (Physico-chemical Analysis Laboratory, IRSEN). 
Table 1 summarizes the chemicals, hardware and software allowing the acquisition of physico-chemical analysis data and data to be estimated from the algorithms for predicting experimental data.

\subsection{Methodologies}

\subsubsection{Location of Sampling Points}

The study takes place on the Djiri river and two sampling points were chosen based on their accessibility for sampling on the Djiri river (Table 2). The geographic coordinates of the upstream (S1) and downstream (S2) points are shown in Table 2.

All samples were taken over 12 months between May 2016 and December 2017 at two points (Upstream and Downstream) chosen because of their accessibility and their proximity to the target industrial site.

\subsubsection{Physico-Chemical Analysis Methodology}

During our study and using plastic bottles of 1.51 liter capacity, washed and rinsed beforehand with demineralized water, the sample is taken by immersing the bottle $25 \mathrm{~cm}$ from the free surface. The water samples, taken, are transported to the laboratory immediately for analysis. 20 physico-chemical parameters were measured to characterize the environment studied between May 2016 and December 2017.

Samples of the water to be analyzed were taken in plastic bottles in areas where water is not stagnant at the upstream point and downstream point from the plant chosen for the study.

Monthly water samples are taken from two selected points on the Djiri River:

- Djiri station (Near Old Djiri Bridge 1st North Exit);

- Manianga (Djiri Bridge 2nd North Exit);

The old Djiri bridge taken as the point of origin;

- Frequency: one sample per month and per sampling point;

- Physico-chemical analyzes at the IRSEN Analysis Laboratory: for the identification of pollutants;

- Concentration of sand by sifting through a $0.0065 \mathrm{~mm}$ sieve;

- Material in suspension by filtration through a 0.45 micrometer filter;

- Dry residue by evaporation at $105^{\circ} \mathrm{C}$ in an oven;

- Ion concentration by a direct spectrometer and palintest.

Sampling marks the starting point of the process of acquiring experimental data.

Table 2. Geographic coordinates of points.

\begin{tabular}{cccc}
\hline SITES & POSITION & $\begin{array}{c}\text { LONGITUDE IN } \\
\text { DECIMAL DEGREES }\end{array}$ & $\begin{array}{c}\text { LATITUDE IN } \\
\text { DECIMAL DEGREES }\end{array}$ \\
\hline S1 & UPSTREAM & 15.3123 & -4.1475 \\
S2 & DOWNSTREAM & 15.4445 & -4.1615 \\
\hline
\end{tabular}

S1: Old Djiri Bridge 1st Exit (Station); S2: Old Djiri Bridge 2nd Exit; The upstream point (S1) is located $1 \mathrm{~km}$ away from the electric steelworks. 
Sampling consists of carrying out a series of water samples from the Djiri river once a month at each point chosen in order to carry out physicochemical analyzes leading to the qualitative state of the waters of the Djiri; These physico-chemical analyzes will take place in the IRSEN's physico-chemical analysis laboratory.

The protocol adopted for the analysis of the samples is spectrophotometry and the spectrophotometric analysis is based on the following parameters.

$\mathrm{PH}, \mathrm{T}^{\circ} \mathrm{C}, \mathrm{CE}, \mathrm{Ca}^{2+}, \mathrm{Mg}^{2+}, \mathrm{K}^{+}, \mathrm{TAC}, \mathrm{NH}_{4}^{+}, \mathrm{Cu}^{2+}, \mathrm{Al}^{3+}, \mathrm{Mn}^{2+}, \mathrm{SO}_{4}^{2-}, \mathrm{PO}_{4}^{3-}$, $\mathrm{Fe}^{\text {tot }}, \mathrm{NO}_{3}^{-}, \mathrm{Cr}, \mathrm{Cl}^{-}$, Sand, Suspended matter, Dry residue.

The principle of this protocol is described as follows.

For each parameter, the sample is calibrated i.e. the measurement of the wavelength of each parameter in the sample is determined;

With the $10 \mathrm{ml}$ water cuvettes, add the reagents (crush the reagent tablets and mix with $10 \mathrm{ml}$ of water);

The mixture obtained by putting together the crushed pellets and $10 \mathrm{ml}$ of water, is placed in a direct spectrophotometer and the measurements immediately appear on the screen of the spectrophotometer (Table 3 ).

Table 3. Codes used for the physico-chemical and metallic parameters evaluated.

\begin{tabular}{|c|c|}
\hline SYMBOL & DESIGNATION \\
\hline $\mathrm{Al}^{3+}$ & Aluminium \\
\hline $\mathrm{Ca}^{2+}$ & Calcium \\
\hline $\mathrm{CE}$ & electrical conductivity \\
\hline $\mathrm{Cl}^{-}$ & chlorine \\
\hline $\mathrm{Cr}$ & Chromium \\
\hline $\mathrm{Cu}^{2+}$ & Copper \\
\hline $\mathrm{Fe}^{\mathrm{tot}}$ & Total iron \\
\hline $\mathrm{K}^{+}$ & Potassium \\
\hline MES & Suspended matter \\
\hline $\mathrm{Mg}^{2+}$ & Magnesium \\
\hline $\mathrm{Mn}^{2+}$ & Manganese \\
\hline $\mathrm{NH}_{4}^{+}$ & Ammonium \\
\hline $\mathrm{NO}_{3}^{-}$ & Nitrate \\
\hline $\mathrm{Pb}^{2+}$ & Lead \\
\hline $\mathrm{PH}$ & Hydrogen potential \\
\hline $\mathrm{PO}_{4}^{3-}$ & Phosphate \\
\hline RS & Dry residue \\
\hline sables & Sand \\
\hline $\mathrm{SO}_{4}^{2-}$ & Sulfate \\
\hline $\mathrm{T}^{\circ} \mathrm{C}$ & Temperature in degrees Celcius \\
\hline TAC & Full alkalimetric titer \\
\hline
\end{tabular}




\subsubsection{Metallic Pollution Assessment Methodology}

- Determination of the in situ measurement excess $\Delta_{\mathrm{C}}$ between the downstream point and the upstream point for each physico-chemical, chemical or metallic parameter at each point and at each moment:

$$
\Delta_{\mathrm{C}}=\text { Measured }_{\text {Downstream }}-\text { Measured }_{\text {Upstream }}
$$

- Indice de Pollution IP pour chaque paramètre en chaque point et à chaque instant:

$$
\mathrm{IP}=\frac{\Delta_{\mathrm{C}}}{\text { Guide }_{\text {Value }}}
$$

If IP > 1 Then the OMS guide value has been exceeded for the parameter analyzed otherwise no exceedance is observed.

- Pollution degree for each parameter at each point and at each moment:

Pollution degree for each parameter at each point and at each moment:

$$
\mathrm{D}^{\circ} \mathrm{P}=\text { Measured }_{\text {Downstream }}-\text { Guide }_{\text {GuidValue }}
$$

If $\mathrm{D}^{\circ} \mathrm{P}>$ Measured_Upstream Then there is pollution otherwise no pollution observed.

\section{- Evaluation of the metal flux:}

The flux is defined as the mass of the pollutant flowing over a surface in one year, it is expressed in tonnes per year.

$$
\text { Metallic }_{\text {Flux }}=31.536 * \text { Average }_{\text {Daily }_{\text {Flux }}} * \text { Over }_{\text {measurement }}
$$

\section{Minimum metal Flux:}

If IP $>1$ then $\Delta_{\mathrm{C}}>\mathrm{WHO}_{\text {Guide }_{\text {value }}}$

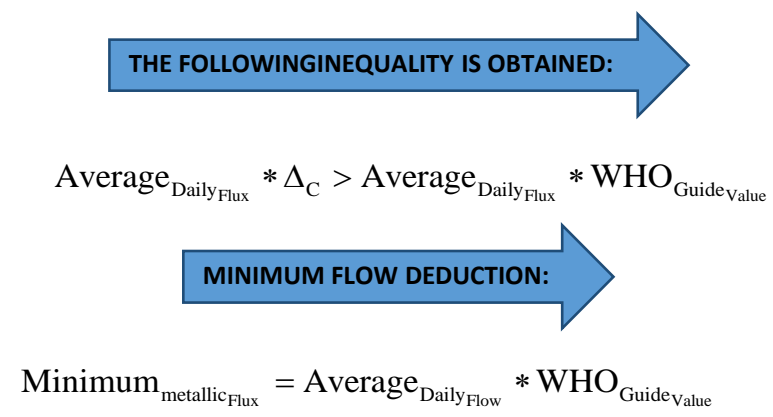

The minimum flux is the flux corresponding to a pollutant concentration equivalent to the WHO guideline value.

\section{Results and Discussion}

\subsection{Results}

\subsubsection{Characterization of the Waters of the Djiri River}

The physico-chemical analyzes of the samples collected enabled the following results to be obtained.

Table 4 illustrates a summary of in situ measurements resulting from sampling carried out on the Djiri river at the downstream point. 
Table 4. Summary of downstream observations [MG/L].

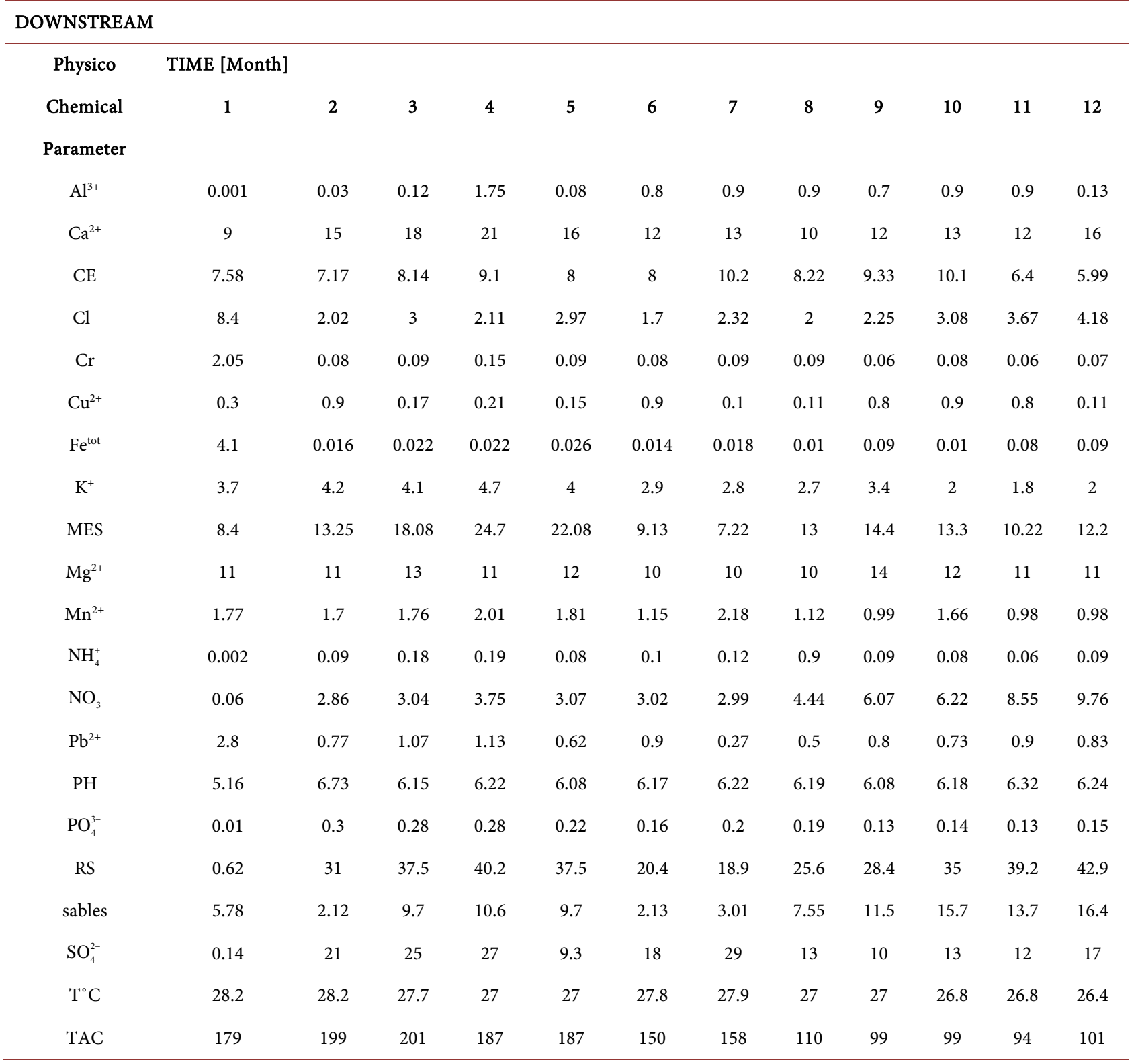

Table 5 illustrates a summary of the in situ measurements resulting from the sampling carried out on the Djiri river at the upstream point.

Table 6 presents the extreme and average values of the upstream observations:

o The PH oscillates between 5.14 and 6.7, which means that the studied medium is acidic

$(\mathrm{PH}<7)$;

o The electrical conductivity EC oscillates between $4.18 \mu \mathrm{S} / \mathrm{cm}$ and $11.2 \mu \mathrm{S} / \mathrm{cm}$ therefore $\mathrm{EC}<100 \mu \mathrm{S} / \mathrm{cm}$ which implies low mineralization of the water and does not promote the movement of electrical charges in the water, in particular ions $\mathrm{Pb}^{2+}$;

o The temperature fluctuates between $26.1^{\circ} \mathrm{C}$ and $28.4^{\circ} \mathrm{C}$; 
o The lead content varies between $0.17 \mathrm{mg} / \mathrm{l}$ and $1.42 \mathrm{mg} / \mathrm{l}$.

Table 7 shows extreme and mean values of downstream observations;

o The PH oscillates between 5.16 and 6.73, which means that the studied medium is acidic $(\mathrm{PH}<7)$;

o The electrical conductivity EC oscillates between $5.99 \mu \mathrm{S} / \mathrm{cm}$ and $10.7 \mu \mathrm{S} / \mathrm{cm}$, therefore $\mathrm{EC}<100 \mu \mathrm{S} / \mathrm{cm}$ which implies a low mineralization of the water and does not promote the movement of electrical charges in the water, in particular ions $\mathrm{Pb}^{2+}$;

o The temperature oscillates between $26.4^{\circ} \mathrm{C}$ and $28.2^{\circ} \mathrm{C}$;

o The lead content varies between $0.27 \mathrm{mg} / \mathrm{l}$ and $2.8 \mathrm{mg} / \mathrm{l}$.

Table 5. Summary of upstream observations $[\mathrm{MG} / \mathrm{L}]$.

\begin{tabular}{|c|c|c|c|c|c|c|c|c|c|c|c|c|}
\hline UPSTREAM & & & & & & & & & & & & \\
\hline Physico & TIME [MG/L] & & & & & & & & & & & \\
\hline Chemical & 1 & 2 & 3 & 4 & 5 & 6 & 7 & 8 & 9 & 10 & 11 & 12 \\
\hline \multicolumn{13}{|l|}{ Parameter } \\
\hline $\mathrm{Al}^{3+}$ & 0.001 & 0.01 & 0.9 & 1.2 & 0.06 & 0.6 & 0.7 & 0.5 & 0.5 & 0.8 & 0.7 & 0.1 \\
\hline $\mathrm{Ca}^{2+}$ & 4 & 40 & 14 & 16 & 6 & 10 & 11 & 9 & 11 & 10 & 11 & 14 \\
\hline $\mathrm{CE}$ & 7.12 & 9.14 & 9.4 & 11.2 & 9.75 & 7.7 & 8.4 & 7.18 & 8.88 & 9.05 & 4.18 & 4.7 \\
\hline $\mathrm{Cl}^{-}$ & 4.5 & 2.26 & 1.8 & 1.87 & 1.3 & 1 & 2.1 & 17 & 2.1 & 1.75 & 2.11 & 3.44 \\
\hline $\mathrm{Cr}$ & 1.6 & 0.06 & 0.08 & 0.09 & 0.09 & 0.06 & 0.08 & 0.05 & 0.04 & 0.06 & 0.05 & 0.06 \\
\hline $\mathrm{Cu}^{2+}$ & 0.3 & 0.6 & 0.15 & 0.17 & 0.9 & 0.8 & 0.9 & 0.6 & 0.5 & 0.6 & 0.6 & 0.8 \\
\hline $\mathrm{Fe}^{\mathrm{tot}}$ & 2.5 & 0.1 & 0.016 & 0.021 & 0.08 & 0.012 & 0.01 & 0.09 & 0.08 & 0.07 & 0.06 & 0.09 \\
\hline $\mathrm{K}^{+}$ & 6 & 2.1 & 3.9 & 3.5 & 44 & 2.2 & 2.7 & 2.1 & 3 & 1.9 & 1.2 & 1.8 \\
\hline MES & 4.5 & 14.9 & 13 & 15.2 & 2.76 & 9 & 11.1 & 10.9 & 11.14 & 10.5 & 8.44 & 11 \\
\hline $\mathrm{Mg}^{2+}$ & 7 & 9 & 10 & 9 & 10 & 8 & 9 & 8 & 10 & 12 & 8 & 9 \\
\hline $\mathrm{Mn}^{2+}$ & 1.64 & 0.75 & 1.55 & 1.17 & 1.17 & 1.1 & 2.14 & 1.07 & 0.97 & 0.98 & 0.95 & 0.82 \\
\hline $\mathrm{NH}_{4}^{+}$ & 0.42 & 0.04 & 0.09 & 0.12 & 0.48 & 0.07 & 0.06 & 0.08 & 0.07 & 0.06 & 0.05 & 0.07 \\
\hline $\mathrm{NO}_{3}^{-}$ & 0.04 & 3.18 & 2.77 & 3.14 & 3.7 & 2.05 & 4.17 & 3.18 & 4.6 & 4.51 & 5.01 & 8.96 \\
\hline $\mathrm{Pb}^{2+}$ & 1.42 & 0.36 & 0.8 & 0.83 & 0.44 & 0.5 & 0.17 & 0.3 & 0.7 & 0.6 & 0.5 & 0.7 \\
\hline $\mathrm{PH}$ & 5.14 & 5.75 & 6.05 & 6.7 & 5.4 & 6.04 & 6.13 & 6.17 & 5.97 & 6 & 6.25 & 6.17 \\
\hline $\mathrm{PO}_{4}^{3-}$ & 0.01 & 0.17 & 0.16 & 0.28 & 0.18 & 0.14 & 0.18 & 0.16 & 0.1 & 0.8 & 0.5 & 0.17 \\
\hline RS & 0.45 & 33.1 & 23.3 & 37.7 & 28.7 & 20 & 27 & 22.9 & 25.7 & 30.1 & 33.7 & 41 \\
\hline sables & 9.91 & 5.5 & 8.2 & 9.12 & 4.79 & 7.4 & 8.04 & 7.12 & 9.18 & 8.5 & 10 & 15 \\
\hline $\mathrm{SO}_{4}^{2-}$ & 0.13 & 3.12 & 20 & 23 & 8.4 & 13 & 8.75 & 11 & 9 & 11 & 10 & 14 \\
\hline $\mathrm{T}^{\circ} \mathrm{C}$ & 28.4 & 28 & 27.9 & 27.2 & 26.4 & 27 & 27.4 & 26.2 & 26.7 & 26.9 & 26.4 & 26.1 \\
\hline TAC & 95 & 187 & 175 & 122 & 95 & 100 & 105 & 99 & 97 & 88 & 84 & 92 \\
\hline
\end{tabular}


Table 6. Extreme and average values of upstream in situ measurements [MG/L].

\begin{tabular}{|c|c|c|c|}
\hline UPSTREAM & & & \\
\hline Physico & & & \\
\hline \multicolumn{4}{|l|}{ Chemical } \\
\hline Parameter & MIN [MG/L] & MAX [MG/L] & AVERAGE [MG/L] \\
\hline $\mathrm{Al}^{3+}$ & 0.001 & 1.2 & 0.505916667 \\
\hline $\mathrm{Ca}^{2+}$ & 4 & 40 & 13 \\
\hline $\mathrm{CE}$ & 4.18 & 11.2 & 8.058333333 \\
\hline $\mathrm{Cl}^{-}$ & 1 & 17 & 3.435833333 \\
\hline $\mathrm{Cr}$ & 0.04 & 1.6 & 0.193333333 \\
\hline $\mathrm{Cu}^{2+}$ & 0.15 & 0.9 & 0.576666667 \\
\hline $\mathrm{Fe}^{\mathrm{tot}}$ & 0.01 & 2.5 & 0.26075 \\
\hline $\mathrm{K}^{+}$ & 1.2 & 44 & 6.2 \\
\hline MES & 2.76 & 15.2 & 10.20333333 \\
\hline $\mathrm{Mg}^{2+}$ & 7 & 12 & 9.083333333 \\
\hline $\mathrm{Mn}^{2+}$ & 0.75 & 2.14 & 1.1925 \\
\hline $\mathrm{NH}_{4}^{+}$ & 0.04 & 0.48 & 0.134166667 \\
\hline $\mathrm{NO}_{3}^{-}$ & 0.04 & 8.96 & 3.775833333 \\
\hline $\mathrm{Pb}^{2+}$ & 0.17 & 1.42 & 0.61 \\
\hline $\mathrm{PH}$ & 5.14 & 6.7 & 5.980833333 \\
\hline $\mathrm{PO}_{4}^{3-}$ & 0.01 & 0.8 & 0.2375 \\
\hline RS & 0.45 & 41 & 26.97083333 \\
\hline sables & 4.79 & 15 & 8.563333333 \\
\hline $\mathrm{SO}_{4}^{2-}$ & 0.13 & 23 & 10.95 \\
\hline $\mathrm{T}^{\circ} \mathrm{C}$ & 26.1 & 28.4 & 27.05 \\
\hline TAC & 84 & 187 & 111.5833333 \\
\hline
\end{tabular}

Table 7. Extreme and average values of downstream in situ measurements [MG/L].

\begin{tabular}{cccc}
\hline DOWNSTREAM & & & \\
\hline Physico & & & \\
\hline Chemical & MIN [MG/L] & MAX [MG/L] & AVERAGE [MG/L] \\
\hline Parameter & 0.001 & 1.75 & 0.600916667 \\
\hline $\mathrm{Al}^{3+}$ & 9 & 21 & 13.91666667 \\
$\mathrm{Ca}^{2+}$ & 5.99 & 10.2 & 8.185833333 \\
$\mathrm{CE}$ & 1.7 & 8.4 & 3.141666667 \\
$\mathrm{Cl}^{-}$ & 0.06 & 2.05 & 0.249166667 \\
$\mathrm{Cr}^{2+}$ & 0.1 & 0.9 & 0.454166667 \\
\hline
\end{tabular}




\begin{tabular}{cccc}
\hline $\mathrm{Fe}^{\text {tot }}$ & 0.01 & 4.1 & 0.374833333 \\
$\mathrm{~K}^{+}$ & 1.8 & 4.7 & 3.191666667 \\
$\mathrm{MES}$ & 7.22 & 24.7 & 13.83166667 \\
$\mathrm{Mg}^{2+}$ & 10 & 14 & 11.33333333 \\
$\mathrm{Mn}^{2+}$ & 0.98 & 2.18 & 1.509166667 \\
$\mathrm{NH}_{4}^{+}$ & 0.002 & 0.9 & 0.165166667 \\
$\mathrm{NO}_{3}^{-}$ & 0.06 & 9.76 & 4.485833333 \\
$\mathrm{~Pb}^{2+}$ & 0.27 & 2.8 & 0.943333333 \\
$\mathrm{PH}^{2-}$ & 5.16 & 6.73 & 6.145 \\
$\mathrm{PO}_{4}^{3}$ & 0.01 & 0.3 & 0.1825 \\
$\mathrm{RS}^{2-}$ & 0.62 & 42.9 & 29.76833333 \\
$\mathrm{sables}^{2-}$ & 2.12 & 16.4 & 8.990833333 \\
$\mathrm{TO}_{4}^{\circ} \mathrm{C}$ & 0.14 & 29 & 16.20333333 \\
$\mathrm{TAC}^{2-1}$ & 26.4 & 28.2 & 27.316666667 \\
\hline
\end{tabular}

\subsubsection{Water Pollution Assessment}

\section{o Spatial variation of experimental measurement}

Table 8 illustrates the in situ measurement differences between the downstream point and the upstream point. It emerges from this illustration that three parameters have strictly positive measurement deviations on all the measurements: lead, magnesium and manganese.

\section{o Metal Pollution Index}

Applying the method described in 3.2.2 gives results listed in the following table.

The 2006 WHO standards do not define a guide value for magnesium because it is considered a trace element.

Table 9 indicates that only lead has pollution indices strictly greater than unity at all times and implies as the choice of pollutant to follow: Lead.

\section{o Determination of the Pollution Index, Pollution Degree on Lead.}

The results on the assessment of water pollution come from the application of the assessment method adopted in 3.2.2. The result of this evaluation is that only lead has a pollution index strictly greater than unity, a degree of pollution (pollution indicator) above the experimental measurement upstream and a metal flow transported above the flow Medium at all times.

Table 10 presents, on the one hand, pollution indices above the WHO guide value for lead and, on the other hand, pollution degrees above in situ measurements downstream, which indicates water pollution with lead.

o Seasonal variation of experimental measurement

Seasonally, there are variations in the average measurement between the rainy season and the dry season upstream and downstream, indicating the pollution is more evident in the rainy season than in the dry season (Table 11). 
Table 8. Measurement excess between the upstream point and the downstream point.

\begin{tabular}{|c|c|c|c|c|c|c|c|c|c|c|c|c|}
\hline Over measurement & {$[\mathrm{MG} / \mathrm{L}]$} & & & & & & & & & & & \\
\hline Physico-Chemical & TIME [Month] & & & & & & & & & & & \\
\hline Parameter & 1 & 2 & 3 & 4 & 5 & 6 & 7 & 8 & 9 & 10 & 11 & 12 \\
\hline $\mathrm{Al}^{3+}$ & 0 & 0.02 & -0.78 & 0.55 & 0.02 & 0.2 & 0.2 & 0.4 & 0.2 & 0.1 & 0.2 & 0.03 \\
\hline $\mathrm{Ca}^{2+}$ & 5 & -25 & 4 & 5 & 10 & 2 & 2 & 1 & 1 & 3 & 1 & 2 \\
\hline $\mathrm{CE}$ & 0.46 & -1.97 & -1.26 & -2.1 & -1.75 & 0.3 & 1.8 & 1.04 & 0.45 & 1.05 & 2.22 & 1.29 \\
\hline $\mathrm{Cl}^{-}$ & 3.9 & -0.24 & 1.2 & 0.24 & 1.67 & 0.7 & 0.22 & -15 & 0.15 & 1.33 & 1.56 & 0.74 \\
\hline $\mathrm{Cr}$ & 0.45 & 0.02 & 0.01 & 0.06 & 0 & 0.02 & 0.01 & 0.04 & 0.02 & 0.02 & 0.01 & 0.01 \\
\hline $\mathrm{Cu}^{2+}$ & 0 & 0.3 & 0.02 & 0.04 & -0.75 & 0.1 & -0.8 & -0.49 & 0.3 & 0.3 & 0.2 & -0.69 \\
\hline $\mathrm{Fe}^{\mathrm{tot}}$ & 1.6 & -0.08 & 0.006 & 0.001 & -0.054 & 0.002 & 0.008 & -0.08 & 0.01 & -0.06 & 0.02 & 0 \\
\hline $\mathrm{K}^{+}$ & -2.3 & 2.1 & 0.2 & 1.2 & -40 & 0.7 & 0.1 & 0.6 & 0.4 & 0.1 & 0.6 & 0.2 \\
\hline MES & 3.9 & -1.65 & 5.08 & 9.5 & 19.32 & 0.13 & -3.88 & 2.1 & 3.26 & 2.8 & 1.78 & 1.2 \\
\hline $\mathrm{Mg}^{2+}$ & 4 & 2 & 3 & 2 & 2 & 2 & 1 & 2 & 4 & 0 & 3 & 2 \\
\hline $\mathrm{Mn}^{2+}$ & 0.13 & 0.95 & 0.21 & 0.84 & 0.64 & 0.05 & 0.04 & 0.05 & 0.02 & 0.68 & 0.03 & 0.16 \\
\hline $\mathrm{NH}_{4}^{+}$ & -0.42 & 0.05 & 0.09 & 0.07 & -0.4 & 0.03 & 0.06 & 0.82 & 0.02 & 0.02 & 0.01 & 0.02 \\
\hline $\mathrm{NO}_{3}^{-}$ & 0.02 & -0.32 & 0.27 & 0.61 & -0.63 & 0.97 & -1.18 & 1.26 & 1.47 & 1.71 & 3.54 & 0.8 \\
\hline $\mathrm{Pb}^{2+}$ & 1.38 & 0.41 & 0.27 & 0.3 & 0.18 & 0.4 & 0.1 & 0.2 & 0.1 & 0.13 & 0.4 & 0.13 \\
\hline $\mathrm{PH}$ & 0.02 & 0.98 & 0.1 & -0.48 & 0.68 & 0.13 & 0.09 & 0.02 & 0.11 & 0.18 & 0.07 & 0.07 \\
\hline $\mathrm{PO}_{4}^{3-}$ & 0 & 0.13 & 0.12 & 0 & 0.04 & 0.02 & 0.02 & 0.03 & 0.03 & -0.66 & -0.37 & -0.02 \\
\hline $\mathrm{RS}$ & 0.17 & -2.1 & 14.2 & 2.5 & 8.8 & 0.4 & -8.1 & 2.7 & 2.7 & 4.9 & 5.5 & 1.9 \\
\hline sables & -4.13 & -3.38 & 1.5 & 1.48 & 4.91 & -5.27 & -5.03 & 0.43 & 2.32 & 7.2 & 3.7 & 1.4 \\
\hline $\mathrm{SO}_{4}^{2-}$ & 0.01 & 17.88 & 5 & 4 & 0.9 & 5 & 20.25 & 2 & 1 & 2 & 2 & 3 \\
\hline $\mathrm{T}^{\circ} \mathrm{C}$ & -0.2 & 0.2 & -0.2 & -0.2 & 0.6 & 0.8 & 0.5 & 0.8 & 0.3 & -0.1 & 0.4 & 0.3 \\
\hline TAC & 84 & 12 & 26 & 65 & 92 & 50 & 53 & 11 & 2 & 11 & 10 & 9 \\
\hline
\end{tabular}

Source: Physico-chemical analysis laboratory, IRSEN.

Table 9. Determination of the pollution index.

\begin{tabular}{|c|c|c|c|c|c|c|}
\hline $\mathrm{Mg}^{2+}$ & $\mathrm{Mn}^{2+}$ & $\mathrm{Pb}^{2+}$ & WHO Guide Value & WHO Guide Value & IP-Mn & $\mathrm{IP}-\mathrm{Pb}$ \\
\hline$[\mathrm{MG} / \mathrm{L}]$ & [MG/L] & [MG/L] & $\mathrm{Mn}[\mathrm{mg} / \mathrm{l}]$ & OMS du $\mathrm{Pb}[\mathrm{mg} / \mathrm{l}]$ & & \\
\hline 4 & 0.13 & 1.38 & 0.4 & 0.01 & 0.325 & 138 \\
\hline 2 & 0.95 & 0.41 & 0.4 & 0.01 & 2.375 & 41 \\
\hline 3 & 0.21 & 0.27 & 0.4 & 0.01 & 0.525 & 27 \\
\hline 2 & 0.84 & 0.3 & 0.4 & 0.01 & 2.1 & 30 \\
\hline 2 & 0.64 & 0.18 & 0.4 & 0.01 & 1.6 & 18 \\
\hline 2 & 0.05 & 0.4 & 0.4 & 0.01 & 0.125 & 40 \\
\hline 1 & 0.04 & 0.1 & 0.4 & 0.01 & 0.1 & 10 \\
\hline 2 & 0.05 & 0.2 & 0.4 & 0.01 & 0.125 & 20 \\
\hline 4 & 0.02 & 0.1 & 0.4 & 0.01 & 0.05 & 10 \\
\hline 0 & 0.68 & 0.13 & 0.4 & 0.01 & 1.7 & 13 \\
\hline 3 & 0.03 & 0.4 & 0.4 & 0.01 & 0.075 & 40 \\
\hline 2 & 0.16 & 0.13 & 0.4 & 0.01 & 0.4 & 13 \\
\hline
\end{tabular}


Table 10. Determination of the pollution index, pollution degree.

\begin{tabular}{|c|c|c|c|c|c|c|c|c|}
\hline & TIME & DOWNSTREAM & UPSTREAM & WHO Guide & Average Excess & Pollution & Pollution & Observation \\
\hline & \multirow[t]{2}{*}{ [Month] } & MEASURE & MEASURE & Value OMS Pb & measurement & Index & degree & \\
\hline & & [MG/L] & {$[\mathrm{MG} / \mathrm{L}]$} & {$[\mathrm{MG} / \mathrm{L}]$} & {$[\mathrm{MG} / \mathrm{L}]$} & & {$[\mathrm{MG} / \mathrm{L}]$} & \\
\hline & 1 & 2.8 & 1.42 & 0.01 & 1.38 & 138 & 2.79 & Pollution \\
\hline & 2 & 0.77 & 0.36 & 0.01 & 0.41 & 41 & 0.76 & Pollution \\
\hline & 3 & 1.07 & 0.8 & 0.01 & 0.27 & 27 & 1.06 & Pollution \\
\hline & 4 & 1.13 & 0.83 & 0.01 & 0.3 & 30 & 1.12 & Pollution \\
\hline & 5 & 0.62 & 0.44 & 0.01 & 0.18 & 18 & 0.61 & Pollution \\
\hline \multirow[t]{10}{*}{ LEAD } & 6 & 0.9 & 0.5 & 0.01 & 0.4 & 40 & 0.89 & Pollution \\
\hline & 7 & 0.27 & 0.17 & 0.01 & 0.1 & 10 & 0.26 & Pollution \\
\hline & 8 & 0.5 & 0.3 & 0.01 & 0.2 & 20 & 0.49 & Pollution \\
\hline & 9 & 0.8 & 0.7 & 0.01 & 0.1 & 10 & 0.79 & Pollution \\
\hline & 10 & 0.73 & 0.6 & 0.01 & 0.13 & 13 & 0.72 & Pollution \\
\hline & 11 & 0.9 & 0.5 & 0.01 & 0.4 & 40 & 0.89 & Pollution \\
\hline & 12 & 0.83 & 0.7 & 0.01 & 0.13 & 13 & 0.82 & Pollution \\
\hline & \multicolumn{8}{|c|}{ Average } \\
\hline & & & & & & Pollution & \multirow{2}{*}{\multicolumn{2}{|c|}{0.93333}} \\
\hline & & & & & & Degree & & \\
\hline
\end{tabular}

Table 11. Seasonal measure excess.

\begin{tabular}{cccccccc}
\hline & SEASON & \multicolumn{3}{c}{ WHO Guide } \\
\hline AVERAGE DOWNSTREAM MEASUREMENT & SP & SS & Variation & Value & OBSERVATION \\
\hline AVERAGE UPSTREAM MEASUREMENT & SP & SS & Variation & Value & OBSERVATION \\
& 0.765 & 0.5325 & 0.2325 & 0.01 & overtaking \\
\hline
\end{tabular}

SS: Rainy season, SP: Dry season.

\section{o Flux variation}

Table 12 shows that the variations in measurements and lead flow between the downstream and upstream of the river are respectively above the WHO guide value and the average flow as illustrated in Figures 1-3.

The quantity of pollutant transported is above the minimum quantity of the identified pollutant (Figure 4) and this confirms the result of Figure 3.

\subsection{Discussion}

The analysis of the physicochemistry data of the surface water of the Djiri river revealed for these waters a temperature ranging from $26.1^{\circ} \mathrm{C}$ to $28.4^{\circ} \mathrm{C}$, an electrical conductivity between 4.18 and 11.2 , a pH between 5.14 and 6.7. 
R. C. Ngoubou et al.

Table 12. Determination of flux.

\begin{tabular}{|c|c|c|c|c|c|c|}
\hline & & AVERAGE & METAL & WHO Guide & Average Measurement & MINIMUM \\
\hline & TIME & DAILY FLOW & FLUX & Value & Excess & FLUX \\
\hline \multirow{12}{*}{ LEAD } & 1 & 20.76 & 903.4685568 & 0.01 & 1.38 & 0.2076 \\
\hline & 2 & 20.7 & 267.646032 & 0.01 & 0.41 & 0.207 \\
\hline & 3 & 20.73 & 176.5101456 & 0.01 & 0.27 & 0.2073 \\
\hline & 4 & 20.52 & 194.135616 & 0.01 & 0.3 & 0.2052 \\
\hline & 5 & 20.73 & 117.6734304 & 0.01 & 0.18 & 0.2073 \\
\hline & 6 & 20.73 & 261.496512 & 0.01 & 0.4 & 0.2073 \\
\hline & 7 & 20.71 & 65.311056 & 0.01 & 0.1 & 0.2071 \\
\hline & 8 & 20.73 & 130.748256 & 0.01 & 0.2 & 0.2073 \\
\hline & 9 & 20.73 & 65.374128 & 0.01 & 0.1 & 0.2073 \\
\hline & 10 & 20.71 & 84.9043728 & 0.01 & 0.13 & 0.2071 \\
\hline & 11 & 20.7 & 261.11808 & 0.01 & 0.4 & 0.207 \\
\hline & 12 & 20.7 & 84.863376 & 0.01 & 0.13 & 0.207 \\
\hline
\end{tabular}

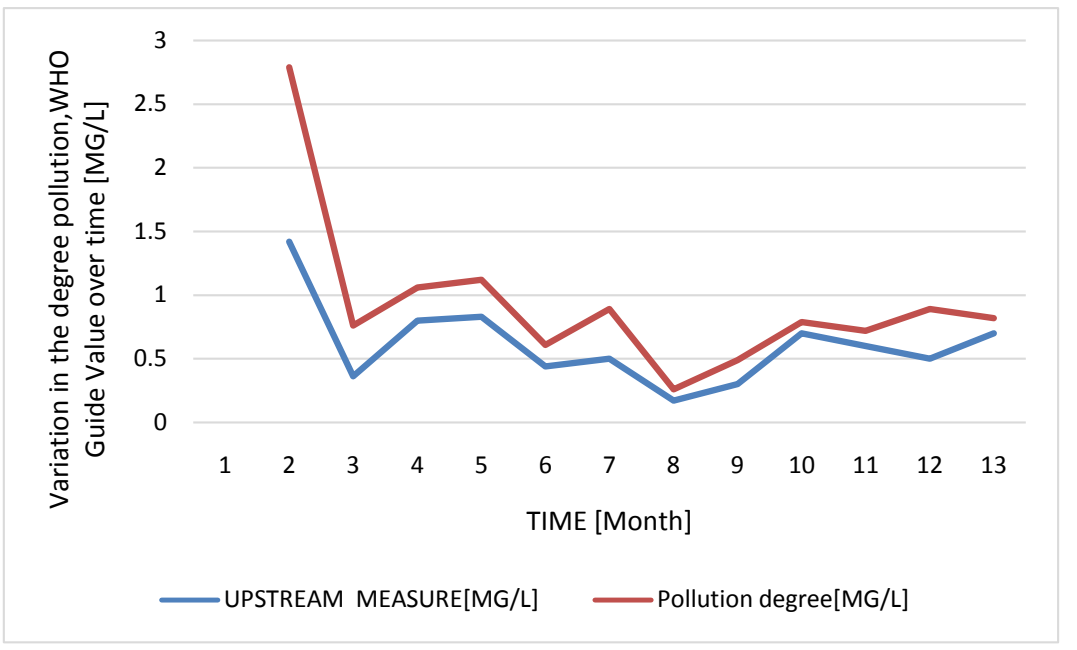

Figure 1. Comparison of Pollution Degree and Measurement upstream of the river.

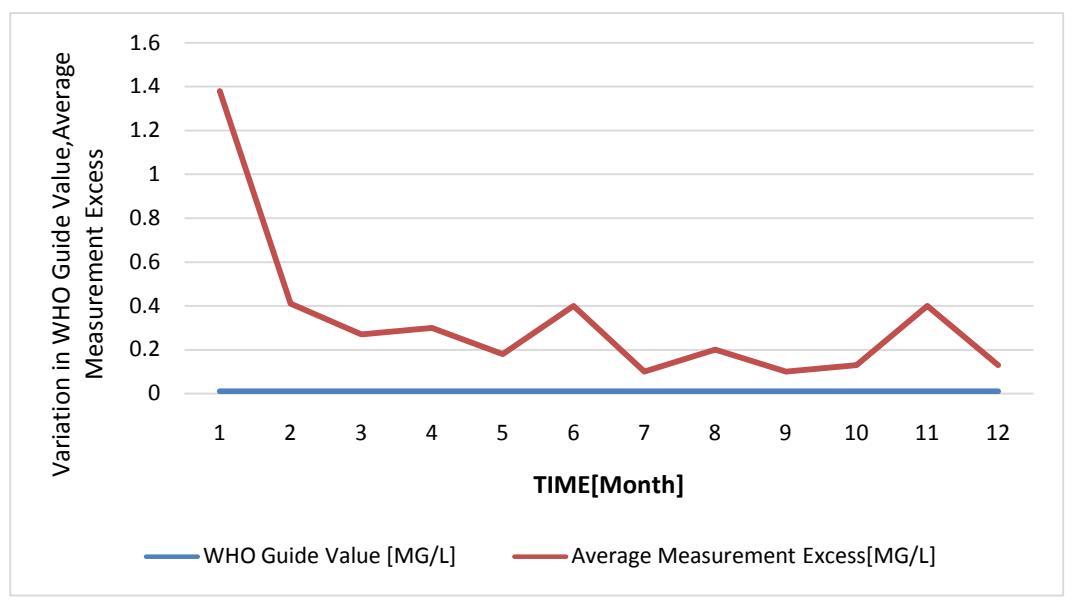

Figure 2. Comparison of in situ measurement excess vs WHO guideline value. 


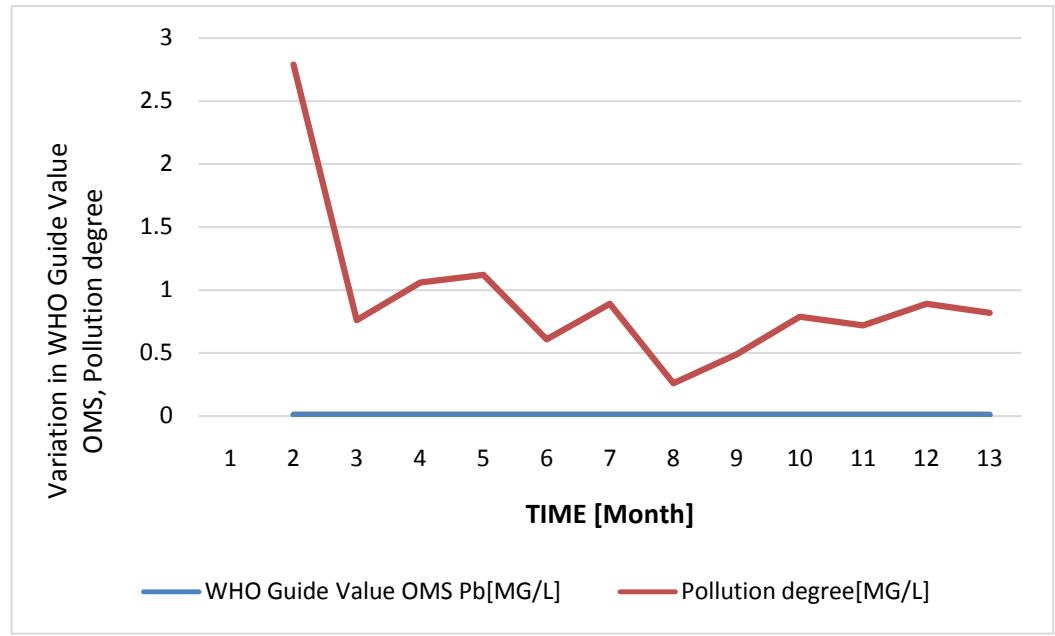

Figure 3. WHO guide value vs Pollution Degree comparison graph.

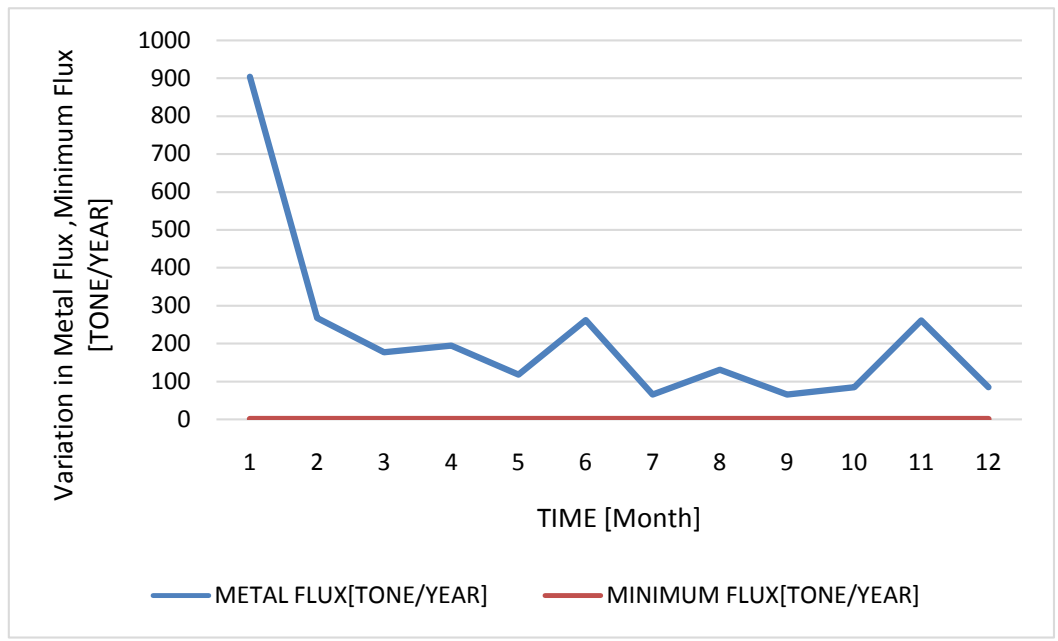

Figure 4. METAL FLUX vs MINIMUM FLUX comparison graph.

The observed $\mathrm{pH}$ values imply a $\mathrm{pH}<7$ and therefore an acidic environment and this increases the risk of the presence of lead in a more toxic ionic form [2]. The values of electrical conductivity observed indicate a weak mineralization of water compared to the conductivity of natural water which is between 50 and $1500 \mu \mathrm{S} / \mathrm{cm}$ and this does not favor the movement of electrical charges, in particular metal ions (lead) which are in principle good conductors of electricity and this induces their accumulation in water;

The methodology used in our study to estimate the metal pollution indices of the surface water of the Djiri river as described in sub-paragraph 3.1.2 makes it possible to verify both that the pollution index (PI) is strictly greater than unity, this implies that the excess measurement is strictly greater than the WHO guideline value and that, consequently, the degree of pollution is greater than the in situ measurement upstream of the river;

It therefore emerges from this pollution assessment that only lead gives, at any time and at each sampling point, monthly excess measurements in situ above the 
WHO water potability standard, which implies a source of metallic lead pollution between downstream and upstream of the Djiri river. This pollution identified in the surface waters of the Djiri river is similar to the results of the pollution study observed in African rivers and in other continents. As the geology of the Djiri watershed is essentially made up of sands, the existence of a source of lead emissions other than the electric steelworks which is installed upstream of the river $1 \mathrm{~km}$ from the upstream sampling point is excluded.

In addition, the seasonal analysis of the average excess lead measurement shows upstream and downstream variations exceeding the WHO guideline value applied and indicating that during the rainy season, the use of recycled scrap metal debris in the study area to compensate for landslides contributes more to the pollution of the waters of the Djiri river than in the dry season (Table 11): $1.28 \mathrm{mg} / \mathrm{l}$ in the rainy season compared to $0.77 \mathrm{mg} / \mathrm{l}$ downstream dry season, i.e. a variation of $0.51 \mathrm{mg} / \mathrm{l}$ and $0.76 \mathrm{mg} / \mathrm{l}$ in the wet season and $0.53 \mathrm{mg} / \mathrm{l}$ in the upstream dry season, i.e. a variation of $0.23 \mathrm{mg} / \mathrm{l}$.

The results of our study in terms of diagnosis of metallic pollution are in line with those of other studies of metallic pollution of water carried out in other rivers of the world and in particular.

- The study of pollution by heavy metals and metalloids and which revealed the pollution by lead on certain stations (lead content exceeding the admissible standards) of the waters of the Bou Regreg estuary (coast Atlantic, Morocco), pollution of an anthropogenic nature, with high pollution indices. In fact, exceeding the WHO guideline value at certain stations implies, in the case of our study, strictly positive in situ excess measurements and higher pollution degrees than downstream in situ measurements [3];

- On our study, the point measurements (concentration) of lead or the excess measurements (variation in concentration) between downstream and upstream are strictly positive and above the WHO standard $(0.01 \mathrm{mg} / \mathrm{l})$ involving thus higher degrees of pollution measurements in situ downstream, this joins the study entitled Contribution to the analytical study of pollutants (in particular of heavy metal type) in the waters of the Chari river during its crossing of the city of $\mathrm{N}$ 'Djamena' which revealed anthropogenic lead pollution of the waters of the Chari River (lead content exceeding acceptable standards) [4];

- The study of the quality of surface water and its impact on the environment in the Wilaya of Skikda in Algeria revealed the significant presence of toxic metallic trace elements in the water, in particular the levels lead found in this surface water exceeds the WHO acceptable standard, indicating contamination of the water; the results of our study also reveal the exceedances at each sampling point of the admissible WHO standard and confirm, through the indices and the estimated degree of pollution, values showing lead contamination of the waters of the Djiri river [5];

- Assessment of the risks of pollution by heavy metals ( $\mathrm{Hg}, \mathrm{Cd}, \mathrm{Pb}, \mathrm{Co}, \mathrm{Ni}, \mathrm{Zn})$ 
of the waters and sediments of the Konkouré river estuary in the Republic of Guinea found on some stations levels of trace metal elements, in particular lead, exceeding WHO standards in terms of concentration at the time and point of sampling and this describes the same scenario observed in the results of our study because at any point and at the time of sampling, the lead in situ measurement exceeds permissible WHO standard [6];

- The study entitled "Contribution of the physico-chemical analysis to the evaluation of metallic contamination of seawater on the coast of Agadir, 2016 (southern Morocco)" showed that the metallic contents of seawater show significant variations depending on the sampling areas and seasons, i.e. levels exceeding the acceptable metal contents of the WHO, our study revealed a seasonal variation in water pollution by lead [7].

The pollution of the waters of the Djiri river with lead confirms many cases of pollution observed in Africa and in other continents [8]-[13].

\section{Conclusions}

The physico-chemical analyses carried out on all the samples taken from the Djiri River have revealed a source of lead contamination in the water.

This contamination is linked to the presence of an industrial installation located $1 \mathrm{~km}$ from the selected sampling point upstream of the Djiri watershed, in particular the point located on the old bridge over the Djiri river (Djiri station).

This study is a prelude to the design and production of a tool for valuing hydrological data which will be equipped with the following features.

o Storage of sampling data and physico-chemical analyzes of water;

o Management of hydrometric stations (gauging data, control of stations;

o Support for the scale for monitoring the flows of rivers;

o Have the physico-chemical state of a river at a given period;

o Monitor water pollutants in general;

o Integration of environmental water standards into the system.

This work perspective will greatly contribute to the establishment of a national observatory of hydrological data from rivers with a view to facilitating analyzes related to water quality in order to provide the necessary explanation in the face of the resurgence of water pathologies observed in these watercourses.

\section{Recommendation}

The study recommends that it is essential to set up and apply a mechanism for monitoring the quality of water in rivers at the national level.

Good quality water, that is to say water that meets WHO drinking water standards, will ensure the good health of those who use it.

To guarantee the protection of watercourses or that of the population against possible pollution, the operationality of the monitoring of the water quality of watercourses is required of the bodies responsible for issues of protection of water ecosystems. Thus, to ensure the coverage of water pollution risks and ensure 
the good health of the populations, it is advisable to conceptualize and implement the hydrological data observatory in order to make available the analysis data of water quality and alert from time to time on any exceptions highlighted to make possible corrections.

\section{Recognition}

The authors thank with gratitude the agents of the physico-chemical analysis laboratory of the Institute for Research in Exact and Natural Sciences, the researchers of the Doctoral Training in Geosciences of the Faculty of Sciences and Techniques of the University Marien NGOUABI, for their immense contribution.

\section{Data Availability}

The data used to support the conclusions of this study are included in the article.

\section{Conflicts of Interest}

The authors declare no conflicts of interest regarding the publication of this paper.

\section{References}

[1] Les lignes directrices de l'OMS sur la qualité de l'eau potable, mises à jour (2006) https://www.lenntech.fr/applications/potable/normes/normes-oms-eau-potable.htm \#ixzz6nwgn7Zn2

[2] Gzara, L., Hafiane, A. and Dhahbi, M. (2000) Rétention des ions Plomb (II) en milieu acide par ultrafiltration assistée par les micelles. Journal of Water Science, 13, 289-304. https://doi.org/10.7202/705395ar

[3] Nadem, S., El Baghdadi, M., Rais, J. and Barakat, A. (2015) Evaluation de la contamination en métaux lourds des sédiments de l'estuaire de Bou Regreg (Côte atlantique, Maroc). Journal of Materials and Environmental Science, 6, 3338-3345.

[4] Ngaram, N. (2011) Contribution à l'étude analytique des polluants (en particulier de type métaux lourds) dans les eaux du fleuve Chari lors de sa traversée de la ville de N’Djamena. Chimie analytique. Université Claude Bernard, Lyon I.

[5] Belhadj, M.Z. and Boudoukha, A. (2017) Qualité des eaux de surface et leur impact sur l'environnement dans la Wilaya De Skikda (Nord-est de l'Algérie). Université Mohamed Khider Biskra, Biskra.

[6] Onivogui, G., Balde, S., Bangoura, K. and Barry, M.K. (2013) Évaluation des risques de pollution en métaux lourds ( $\mathrm{Hg}, \mathrm{Cd}, \mathrm{Pb}, \mathrm{Co}, \mathrm{Ni}, \mathrm{Zn}$ ) des eaux et des sédiments de l'estuaire du fleuve Konkouré (Rep. de Guinée). Afrique SCIENCE, 9, 36-44.

[7] Chaouay, A., Okhrib, R., Hilali, M., Bazzi, L., Chahid, A. and Khiri, F. (2016) Contribution à l'étude de l'analyse physico-chimique et de la contamination métallique de l'eau de mer du littoral d'Agadir. Journal of Materials and Environmental Science, 7, 2748-2759.

[8] Tanouayi, G., Gnandi, K., Ahoudi, H. and Ouro-Sama, K. (2015) la contamination métallique des eaux de surface et des eaux souterraines de la zone minière d'exploitation des phosphates de HAHOTOE-KPOGAME (sud Togo): Cas du Cadmium, Plomb, Cuivre et Nikel. Larhyss Journal, No. 21, 35-50. 
[9] Arnac, M. (1976) Variations des teneurs en $\mathrm{Cd}, \mathrm{Pb}$ et $\mathrm{Cu}$ dans les eaux de l'estuaire maritime du St-Laurent Durant l'été 1972. Marine Chemistry, 4, 175-187. https://doi.org/10.1016/0304-4203(76)90006-2

[10] Pitrat, D.M.J.J. and Braga, M.C.B. (2012) Évaluation de la contamination métallique d'une ressource en eau de la ville de Curitiba, Brésil. VertigO-la revue électronique en sciences de l'environnement, 12, No. 1.

http://journals.openedition.org/vertigo/11945

[11] InVS (2006) Erratum concernant le guide méthodologique. Dépistage du saturnisme infantile autour des sources industrielles de plomb. Tome 1: analyse de la pertinence de la mise en œuvre d'un dépistage: du diagnostic environnemental à l'estimation des expositions. Édition InVS, 2006.

[12] Oukhrib, R. (2019) Contribution to the Study of Physico-Chemical Analysis and Metal Contamination of Coastal AGADIR Seawater (South Morocco). Journal of Materials and Environmental Science, 7, 2748-2759.

[13] Djade, P.J.O., et al. (2020) Evaluation du niveau de contamination des eaux souterraines par les éléments traces métalliques dans le département de Zouan-Hounien (Ouest de la Côte d'Ivoire). Journal of Applied Biosciences, 150, 15457-15468.

https://doi.org/10.35759/JABs.150.6 